\title{
Validation of a Quantitative Analysis Method for Collagen Extracted from Grey Mullet Marine Fish
}

\author{
RODICA SIRBU ${ }^{1}$, GABRIELA STANCIU2*, EMIN CADAR ${ }^{1}$, ANETA TOMESCUㄴ, MELAT CHERIM ${ }^{1}$ \\ ${ }^{1}$ Ovidius University of Constanta, Faculty of Pharmacy, 124 Mamaia Blvd., 900527, Constanta, Romania \\ ${ }^{2}$ Ovidius University of Constanta, Depart. of Chemistry and Chemical Engineering, 124 Mamaia Blvd., 900527, Romania \\ ${ }^{3}$ Ovidius University of Constanta, Faculty of Medicine, 124 Mamaia Blvd., 900527, Constanta, Romania
}

\begin{abstract}
The Black Sea offers numerous harnessing possibilities for the medical and pharmaceutical, agricultural, food industry and cosmetic fields. Collagen extraction from the Black Sea fish is a research area of great interest. The purpose of this paper is to optimize the collagen quantitative analysis method based on hydroxyproline reagent through visible molecular absorption spectrometry. The adapted method was validated, achieving the following performance criteria: linearity, detection and quantification limits, accuracy/ fidelity, stability/sturdiness, repeatability, and measurement uncertainty. The validated method was applied for the quantitative determination of collagen content in Grey Mullet fish and for the evaluation of collagen extraction output.
\end{abstract}

Keywords: fish collagen, quantitative analysis validation, spectrophotometry, hydroxyproline

The presence of collagen in almost all vital organs and tissues of living organisms, as well as its structural and biochemical particularities have drawn the attention of researchers worldwide regarding the importance of this protein. Collagen is a natural polymer, consisting of a characteristic sequence of 20 aminoacids with a complex conformational structure, organized on four levels, also called a primary structure [1]. Collagen contains higher amounts of certain aminoacids. Almost a third of collagen is represented by glycine, while another third consists of proline and hydroxyproline. The mostrecent data regarding collagen composition show that hydroxyproline residue is present in the major phenotype I collagen in a proportion of $11.3 \%$ of its weight, while in the type II collagen of cartilages and type IV collagen of basal membranes the proportions vary between $12.9 \%$ and $14.3 \%$, respectively, while in type III collagen it measures to approximately $15 \%$ [2]. Hydroxyproline measurements have been used as markers to quantify levels of collagen and/or gelatin (knowing that the partial hydrolysis of collagen leads to a mixture of proteins and peptides) [3].

Collagen has multiple uses, especially in the pharmaceutical and biomedical fields [4-7]. The most commonly found source of collagen comes from terrestrial mammals. However, due to the risk of bovine spongiform encephalopathy and aphthous fever, from recent years the marine sources of collagen have also come into the spotlight [8-11]. Globally, in order to extract collagen from saltwater fish, or fresh water fish the followings have been used: bones, skin, fins, and scales [12-16]. From the Black Sea, the Grey Mullet fish has been used for obtaining collagen from its skin and scales [17]. In order to ensure the quality of the raw material used, complex and performing methods that can ensure certain and reproducible data are needed.

Samples containing collagen material are first subjected to acid hydrolysis, followed by the quantitative determination of hydroxyproline through high performance liquid chromatography or gas chromatography $[18,19]$, using volatile derivates, such as esters [20], butyl trifluoroacetate, isobutyl or N-heptafluorobutyryl [20, 21]. These are arduous methods that are more suitable for samples with a low content of collagen. The most commonly utilized method remains the spectrophotometric determination of hydroxyproline with an Ehrlich reagent [2, 21, 22]. For collagen rich nourishment products, the ISO 3496: 1994 method is applied [23], which was developed especially for meat products.

The purpose of this paper is the optimization of the quantitative analysis method of collagen obtained from saltwater fish, based on the determination of hydroxyproline content through visible spectrophotometry molecular absorption. The adapted method has been validated, by respecting the following performance criteria: linearity, detection and quantification limits, accuracy/ fidelity, stability/sturdiness, repeatability, and measurement uncertainty. The validated method was applied for the quantitative determination of collagen content in Grey Mullet fish and for the evaluation of collagen extraction output.

\section{Experimental part}

In order to determine the extracted collagen content, it was necessary to optimize a quantitative analysis method, based on the determination of hydroxyproline content [24, 25]. The basic principles for the spectrophotometric determination of hydroxyproline are listed in the ISO 3496/ 1994 standard [23].

\section{Reagents}

Only reagents with a renowned analytical quality were used (Sigma Aldrich) as well as distilled, denionized or water equivalent in purity: $\mathrm{H}_{2} \mathrm{SO}_{4} 3 \mathrm{~mol} / \mathrm{L}$ solution and buffer solution $\mathrm{pH}=6.8$ (prepared from $26 \mathrm{~g}$ of monohydrate citric acid; $14 \mathrm{~g} \mathrm{NaOH} ; 78 \mathrm{~g}$ sodium acetate). The reagents are diluted in $500 \mathrm{~mL}$ and then passed into a $1 \mathrm{~L}$ graded flask. $250 \mathrm{~mL}$ of 1-propanol are added and brought to the graduation mark, chloramine-T solution (1.41 grams of sodium salt of N-chloro-p-toluene sulfonamide in $100 \mathrm{~mL}$ of prepared buffer solution), color reagent, prepared in the day of the use $(10 \mathrm{~g}$ of $\mathrm{p}$-dimethylaminobenzaldehyde in $35 \mathrm{~mL}$ solution of perchloric acid, $60 \%,(\mathrm{~m} / \mathrm{m})$ and $65 \mathrm{~mL}$ isopropanolol). Hydroxyproline standard solution swas obtained from a stock solution prepared in a $100 \mathrm{~mL}$ volumetric flask by dissolving $50 \mathrm{mg}$ of hydroxypirolidine- 
$\alpha$-carbonic - hydroxyproline - in water. A drop of sulphuric acid is added and brought to graduation mark. This solution is maintained stable for a month at $4^{\circ} \mathrm{C}$. On the day of the use, $5 \mathrm{~mL}$ from the stock solution are introduced into a 500 $\mathrm{mL}$ volumetric flask, after which four standard solutions of $0.5 \mu \mathrm{g} / \mathrm{mL}, 1 \mu \mathrm{g} / \mathrm{mL}, 1.5 \mu \mathrm{g} / \mathrm{mL}$ and $2 \mu \mathrm{g} / \mathrm{mL}$ respectively are prepared by taking $10 \mathrm{~mL}, 20 \mathrm{~mL}, 30 \mathrm{~mL}$ and $40 \mathrm{~mL}$ in $100 \mathrm{~mL}$ flasks, completed to graduation mark. The reference material used was TET003 RM from FAPAS.

\section{Equipaments}

A Hellios Omega Thermo Scientific series 1771008 spectrometer was used, suitable for use at a wave length of $558 \mathrm{~nm} \pm 2 \mathrm{~nm}$ Glassware consisted in volumetric flasks and class A pipettes, certified by the producer and internally verified. Also, an adjustable oven at $105^{\circ} \mathrm{C} \pm 2^{\circ} \mathrm{C}$, an analytical scale with an accuracy of $0.0001 \mathrm{~g}$ and a water bath were used.

\section{Methods}

The method is represented by the spectrophotometric determination of hydroxyproline after reaction with the Ehrlich reagent $[3,24]$. The sample to be analyzed is subjected to hydrolysis with sulphuric acid at $105^{\circ} \mathrm{C}$, when collagen is transformed into hydroxyproline; the hydrolysate is filtered, diluted and the hydroxyproline is then oxidized in the presence of chloramine T, and the oxidation product is decarboxylated to pyrrole; next, in the presence of $p$ dimethylaminobenzaldehyde, a red colored compound is formed. Absorbance at a wavelength of $558 \mathrm{~nm}$ is measured using a $1 \mathrm{~cm}$ pathlength cuvette.

The spectrophotometric method allows calculating the percentage of collagen based on the percentage content of hydroxyproline, using the following equation (1):

$$
\text { Content of collagen }=8 \mathrm{~W} \%
$$

where: $\mathrm{W}$ is Hyp content, calculated as mass percentage, while 8 is the transformation factor [23].

\section{Sample preparation}

Method validation was performed on collagen extract obtained with $0.5 \mathrm{M}$ acetic acid. The samples were homogenized. The analysis sample was had $4 \mathrm{~g}$ weighted with an accuracy of $0.001 \mathrm{~g}$ in the hydrolysis flask. $30 \pm 1$ $\mathrm{mL}$ of sulphuric acid solution were added, the flask is covered with a watch glass and kept for $16 \mathrm{~h}$ in the oven at $105^{\circ} \mathrm{C}$. The hydrolysate was filtered at warm, on filter paper, and the filtrate collected in a $250 \mathrm{~mL}$ volumetric flask. The filter paper and the flask were washed three times with 10 $\mathrm{mL}$ of warm sulphuric acid, adding washing liquid to the hydrolysate. It was the completed to graduation mark and homogenized.

In order to form the colored complex and to measure absorbance, a $\mathrm{V}$ volume of hydrolysate is introduced using a pipette into a $250 \mathrm{~mL}$ volumetric flask, so as to allow the obtaining of a hydroxyproline concentration between 0.5 $\mu \mathrm{g} / \mathrm{mL}$ and $2 \mu \mathrm{g} / \mathrm{mL}$. It is then brought to graduation mark. From this solution, $4 \mathrm{~mL}$ were introduced into a tube and 2
$\mathrm{mL}$ of chloramine $\mathrm{T}$ reagent were added. After mixing, it was left at room temperature for $20 \pm 1$ min. Afterwards, $2 \mathrm{~mL}$ of color reagent was added, mixed and the tube was covered with an aluminum foil.

The tube is rapidly introduced in a water bath set at $60^{\circ} \mathrm{C}$ and heated for $20 \mathrm{~min}$. It is then cooled under water jet for $3 \mathrm{~min}$ and keptatroom temperature for $30 \mathrm{~min}$. Absorbance is measured at $558 \pm 2 \mathrm{~nm}$ against the water in a glass spectrophotometer cuvette. Absorbance of the witness sample is deducted from that of the analyzed sample and the hydroxyproline concentration is read on the standard curve. The standard curve is obtained through the same steps previously described, with the exception that the diluted hydrolysate is replaced with $4 \mathrm{~mL}$ of each of the four standard solution, diluted by the hydroxyproline. The standard curve chart is obtained, with the values of absorbencies according to the corresponding concentrations of the standard hydroxyproline solutions. $A$ straight line as possible standard curve, which passes through origin, is drawn.

Collagen extracted from Grey Mullet skin was treated with both amounts of with $0.5 \mathrm{M}$ acetic acid and $0.1 \mathrm{M}$ chlorhydric acid, where $m$ is the mass of analysed sample, in g. Collagen extract samples were subjected to acid hydrolysis and followed the same steps as the reference material. For each sample to be analyzed, the hydroxyproline content (W) is calculated in mass percentages according to the following equation:

$$
\mathrm{W}=\frac{6.25 \mathrm{c}}{\mathrm{mV}} \%
$$

where: $c$ is the hydroxyproline concentration of the diluted hydrolysate read in $\mu \mathrm{g} / \mathrm{mL}$ on the standard curve, and $\mathrm{V}$ is the volume of the part of the hydrolysate collected for dilution at $250 \mathrm{~mL}$. The resultis expressed with an accuracy of $0.01 \%$ [23].

\section{Results and discussions}

Validation of the analysis method

Validation of the method for hydroxyproline content determination was performed according to validation guidelines for analytical methods recommended by EURACHEM [26-28]. Linearity test was performed according to the requirements of the SR ISO 8466-1/199 standard [29]. The work concentration domain was established, represented by the interval between the inferior and superior concentrations of the analyzed sample, through which it was proven that the procedure has an adequate level of precision, exactness and linearity.

The hydroxyproline standard curve was drawn for 6 samples. In the linearity statistical test, standardization data was processed either through a linear function according to $a \mathrm{y}=\mathrm{a}+\mathrm{bx}$ equation or a non-linear function according to a polynomial equation such as $y=a x^{2}+b x+c$. The absorbance values obtained for various concentration of hydroxyproline are presented in table 1 and the standard curve for the linear function is shown in figure 1.

\section{Table 1}

THE VALUES ON THE STANDARD CURVE FOR DETERMINATION OF HYDROXYPROLINE USING VISIBLE MOLECULAR ABSORPTION

\begin{tabular}{|l|l|l|l|l|l|l|}
\hline & 1 & 2 & 3 & 4 & 5 & 6 \\
\hline $\begin{array}{l}\text { Concentration, } \\
\mathrm{mg} / \mathrm{mL}\end{array}$ & 0.500 & 1.000 & 1.500 & 2.000 & 2.500 & 3.500 \\
\hline $\begin{array}{l}\text { Absorbance } \\
\text { (u.a.) }\end{array}$ & 0.101 & 0.179 & 0.279 & 0.370 & 0.480 & 0.633 \\
\hline
\end{tabular}




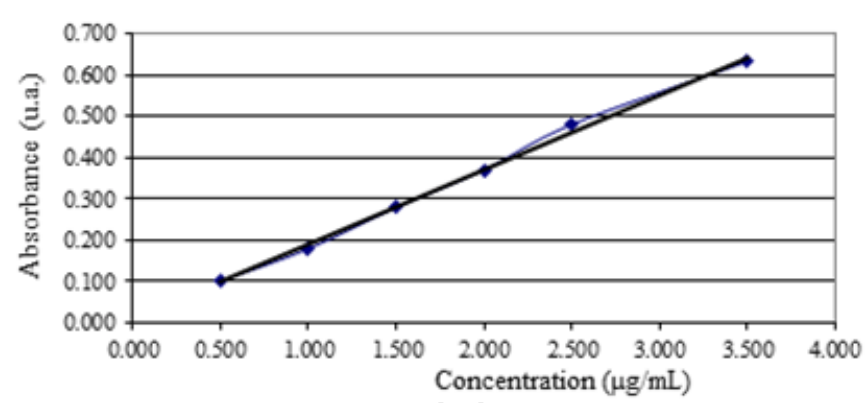

Fig. 1. Standard curve

Spectrometry for all 6 Samples

The standardization data have the following characteristics, which are also presented in tables 2 and 3.

-For the linear standardization function: $y=0.1817 x+$ 0.0072 with $R^{2}=0.9971$, with a residual standard deviation $\mathrm{Sy}_{1}=0.0105$;

-For the non-linear standardization function: $y=-0.0041 x^{2}$

$+0.1983 x-0.0052$ with

$\mathrm{R}^{2}=0.9976$, with a residual standard deviation $\mathrm{Sy}_{2}=$ 0.00965;

Because the two values of residual standard deviations Sy ${ }_{1}$ and Sy, differ, the difference of dispersions (DS2) must be evaluated with the following equation:

$$
\mathrm{DS}^{2}=(\mathrm{N}-2) S \mathrm{Sy}_{1}^{2}-(\mathrm{N}-3) \mathrm{Sy}_{2}^{2}
$$

where: $\mathrm{N}=6$ is samples number and $\mathrm{DS}^{2}$ is difference of dispersions [29].

- PG information values was calculated using the following equation:

$$
\mathrm{PG}=\frac{\mathrm{DS}^{2}}{\mathrm{Sy}_{2}^{2}}
$$

Where: PG is the test value calculated for comparison with the values of Fisher distribution (testul F- FisherSnedecor) [29]. The results obtained depict a standard curve with the correlation coefficient $\mathrm{R}=0.9985$ and $\mathrm{PG}=$ $1.7399<10.97$. It is compared with the $F$ factor $=10.97$ (according to SR ISO 8466-1:1999 Fisher-Snedecor factor value) [29]. Tables 2 and 3 summarize the results obtained for linear and a non-linear standardization function. Because a $P G<F$ was obtained, the non-linear standardization curve does not offer an improved adjustment, so we decided that the standardization function is linear (according to SR ISO 8466-1:1999, pt.4.1.3).

It can be seen that the performance criteria [29] were accomplished because on the selected concentration domain $0.5-3.5 \mathrm{mg} / \mathrm{mL}$, the standard-ization function is linear, the variation coefficient of the method is $\mathrm{Vx}=3.162$ $<10 \%$, the correlation coefficient $\mathrm{R}=0.9985>0.995$, and the informant value, compared to $F=10.97$, is $P G=$ $1.7399<10.97$ ( $N=6$ with 5 degrees of freedom).

\section{Dispersions homogeneity test}

In order to appreciate the homogeneity of dispersions, it was evaluated whether the differences at the ends of the work domain (the first and last concentration point on the standard curve) are significant [29]. In order to do so, the PG informant value is subjected to an $\mathrm{F}$ test which takes into account the number of freedom degrees $f_{i}=n_{i}-1$. For a six-point curve, 5 values were used for each of the two ends of the domain, and, in this case, for $\mathrm{f}=\mathrm{n}-\mathrm{I}=4$ degrees of freedom. The value in the table 4 is $F=15.98$. The results of the homogeneity test are presented also in table 4. Because $\mathrm{S}_{6}^{2}>\mathrm{S}_{1}^{2} \mathrm{PG}$ informant values are calculated from the condition given by the equation (5):

$$
P G=S_{6}^{2} / S_{1}^{2}
$$

As it is outlined in table 4, an informant value $P G=$ $11.27<15.98$ was obtained; this indicates the fact that the deviation between dispersions at the ends of the working domain is not significant and that the dispersions are thus homogenous. The working domain is adequate due to the fact that it adheres to linearity alongside the entire chosen work domain and the calibration curve meets the established performance criteria.

\begin{tabular}{|c|c|c|c|c|}
\hline \multicolumn{5}{|c|}{$y=0.1817 x+0.0072$} \\
\hline $\begin{array}{l}\text { Curve for } 6 \text { samples } \\
N=6\end{array}$ & $\begin{array}{l}\text { Mean concentration } \\
\text { values, } \mathrm{mg} / \mathrm{mL} \\
\bar{x}=1.8333\end{array}$ & $\begin{array}{l}\text { Slope } \\
B=0.1817\end{array}$ & $\begin{array}{l}\text { Intercept } \\
\mathrm{A}=0.0072\end{array}$ & $\begin{array}{l}\text { Residual standard deviation } \\
S y_{1}=\sqrt{\frac{\sum_{1}^{N}\left(y_{i}-\overline{y_{i}}\right)^{2}}{N-1}} \\
S y_{1}=0.0105\end{array}$ \\
\hline $\begin{array}{l}\text { Square residual standard } \\
\text { deviation } \\
\mathrm{Sy}_{1}^{2}=1.1025^{*} 10^{-4}\end{array}$ & $\begin{array}{l}\text { Standard deviation of } \\
\text { the method } \\
S x_{0}=\frac{S y}{b} \\
\text { Where b is slope. } \\
\text { Sxo }=0.0579\end{array}$ & $\begin{array}{l}\text { Correlation } \\
\mathrm{R}^{2}=0.9971\end{array}$ & ícient & $\begin{array}{l}\text { Variation coefficient of the } \\
\text { method } \\
V x_{0}=\frac{S x_{0}}{\bar{x}} 100 \\
V x_{0}=3.162 \% \\
V x_{0}<10 \% \text {. }\end{array}$ \\
\hline
\end{tabular}

Table 2

RESULTS FOR THE LINEAR STANDARDIZATION FUNCTION

\begin{tabular}{|c|c|c|c|}
\hline \multicolumn{4}{|c|}{ Linear standard curve $y=-0.0041 x^{2}+0.1983 x-0.0052$} \\
\hline $\begin{array}{l}\text { Linear standard curve for } 6 \\
\text { samples } \\
\mathrm{N}=6\end{array}$ & $\begin{array}{l}\text { Mean concentration } \\
\text { value, } \mathrm{mg} / \mathrm{mL} \\
\bar{x}=1.8333\end{array}$ & $\begin{array}{l}\text { Residual standard deviation, } \\
S y_{2}=\sqrt{\frac{\sum_{t}^{N}\left(y_{t}-\bar{y}_{t}\right)^{2}}{N-1}} \\
S y_{2}=0.00965\end{array}$ & $\begin{array}{l}\text { Square residual standard } \\
\text { deviation, } S_{2}^{2}=9.3061 \sigma^{-5}\end{array}$ \\
\hline \multicolumn{2}{|l|}{$\begin{array}{l}\text { Correlation coefficient: } \\
\mathrm{R}^{2}=0.9976\end{array}$} & \multicolumn{2}{|c|}{$\begin{array}{l}\mathrm{DS}^{2}=(\mathrm{N}-2) \mathrm{Sy}_{1}^{2}-(\mathrm{N}-3) \mathrm{Sy}_{2}^{2}=16182 * 10^{4} \\
\mathrm{PG}=\frac{\mathrm{DS}^{2}}{\mathrm{Sy}_{2}^{2}}=1.7399 \triangleleft 10.97\end{array}$} \\
\hline
\end{tabular}

Table 3

RESULTS FOR NON-LINEAR STANDARDIZATION FUNCTION 
Table 4

DISPERSION HOMOGENEITY TEST AT THE ENDS OF THE WORKING DOMAIN

\begin{tabular}{|c|c|c|c|c|c|c|c|c|}
\hline \multirow{2}{*}{$\begin{array}{l}\text { Sample } \\
\text { no. }\end{array}$} & Concentration, $\mathrm{x}$ & \multicolumn{5}{|c|}{ Absorbance response, $y$} & STDEV & STDEV $^{2}$ \\
\hline & $\mathrm{mg} / \mathrm{mL}$ & \multicolumn{5}{|c|}{ u.a., $n=5$ repetitions } & & \\
\hline 1 & 0.5 & 0.113 & 0.094 & 0.116 & 0.101 & 0.1 & $\mathrm{~S}_{1}=0.00931$ & $\mathrm{~S}_{1}{ }^{2}=8.67 * 10^{-5}$ \\
\hline 6 & 3.5 & 0.718 & 0.66 & 0.665 & 0.633 & 0.657 & $\mathrm{~S}_{6}=0.03126$ & $\mathrm{~S}_{6}{ }^{2}=9.773^{*} 10^{-4}$ \\
\hline \multicolumn{5}{|c|}{ For freedom degrees $n-1=4$} & $F=15.98$ & \multicolumn{2}{|c|}{$P G=11.272203$} & $\mathrm{PG}<\mathrm{F}$ \\
\hline
\end{tabular}

Limit of detection (LOD) and limit of quantification (LOQ)

LOD limit of detection is equal with three times the standard deviation of the mean of the

determinations for the sample blank, and has been calculated for 21 determinations.

LOQ limit of quantification is equal with ten times the standard deviation of the mean of the determination for the sample blank (for 21 determinations), taken into account that both accuracy and precision are constant for an interval of concentrations around the detection limit. Results are presented in table 5.

\section{Recovery}

Before reading the samples, the blank reagent test was performed for the spectrophotometry. In the absence of a sample blank, standard hydroxyproline solution with decreasing concentrations $(0.1 ; 0.05 ; 0.025 \mu \mathrm{g} / \mathrm{mL})$ and their absorbances were registered sequentially. Readings were performed after registering the absorbance of the blank reagent solution ( $<0.040$ u.a) compared to distilled water and setting the spectrophotometer to zero with this value. The reagent blank sample was obtained by replacing the diluted hydrolysate with $4 \mathrm{~mL}$ of distilled water. Thus, 6 repetitions for $0.1 \mu \mathrm{g} / \mathrm{mL}$ hydroxyproline standard samples prepared in the laboratory, 6 repetitions for $0.05 \mu \mathrm{g} / \mathrm{mL}$ standard samples and 2 repetitions for $0.025 \mu \mathrm{g} / \mathrm{mL}$ standard samples were analyzed. Due to the fact that absorbances registered for the $0.025 \mu \mathrm{g} / \mathrm{mL}$ standard were identical with those registered for the $0.05 \mu \mathrm{g} / \mathrm{mL}$ standard, while for those registered for the $0.1 \mu \mathrm{g} / \mathrm{mL}$ were visibly higher, it was convened that LOD will be tested for 0.05 $\mu \mathrm{g} / \mathrm{mL}$ (0.01\% Hyp). 21 repetitions for the $0.05 \mu \mathrm{g} / \mathrm{mL}$ standard solution ( $0.01 \%$ Hydroxyproline) were analyzed according to the work procedure (data are presented in table 6). LOQ was then verified, in repeatability conditions, in order to evaluate exactness and precision.

\section{Repeatability (Precision)}

The precision of the method was evaluated based on repeatability conditions according to SR ISO 3496 / 1997 pt.10.1 [9], with a dependence $r_{\text {max }}=0.0131+0.0322$ $X_{\text {man }}$, which is expected to fall within a probability interval (usually $95 \%$ ), $r$ is the maximum permissible absolute difference between two independent results obtained with

Table 5

HYDROXYPROLINE CONCENTRATION ON THE STANDARD CURVE AND ON THE COLLAGEN SAMPLE OF 4G WEIGHT

\begin{tabular}{|c|c|c|c|c|c|c|c|}
\hline No. of repetitions & 1 & 2 & 3 & 4 & 5 & 6 & 7 \\
\hline $\begin{array}{l}\text { Hyp. c }(\mu \mathrm{g} / \mathrm{mL}) \text { concentration, } \\
\text { calibration curve }\end{array}$ & 0.033 & 0.029 & 0.066 & 0.066 & 0.054 & 0.083 & 0.082 \\
\hline $\begin{array}{l}\text { Hyp } \% \text { concentration, Collagen for } \mathrm{m}=4.00 \mathrm{~g} \\
\text { sample and } \mathrm{V}=4 \mathrm{~mL} \text { hydrolysate with dilution factor } \\
\text { f.d.= } 6.25\end{array}$ & 0.005 & 0.004 & 0.010 & 0.010 & 0.008 & 0.013 & 0.013 \\
\hline No. of repetitions & 8 & 9 & 10 & 11 & 12 & 13 & 14 \\
\hline $\begin{array}{l}\text { Hyp. c }(\mu \mathrm{g} / \mathrm{mL}) \text { concentration, } \\
\text { - calibration curve }\end{array}$ & 0.069 & 0.031 & 0.072 & 0.093 & 0.057 & 0.037 & 0.086 \\
\hline $\begin{array}{l}\text { Hyp. \% concentration, Collagen for } \mathrm{m}=4.00 \mathrm{~g} \\
\text { sample and } \mathrm{V}=4 \mathrm{~mL} \text { hydrolysate with dilution } \\
\text { factor f.d. }=6.25\end{array}$ & 0.011 & 0.005 & 0.011 & 0.014 & 0.009 & 0.006 & 0.009 \\
\hline No. of repetitions & 15 & 16 & 17 & 18 & 19 & 20 & 21 \\
\hline $\begin{array}{l}\text { Hyp. c }(\mu \mathrm{g} / \mathrm{mL}) \text { concentration, } \\
\text { - calibration curve }\end{array}$ & 0.065 & 0.035 & 0.07 & 0.066 & 0.059 & 0.039 & 0.078 \\
\hline $\begin{array}{l}\text { Hyp. \% concentration, Collagen for } \mathrm{m}=4.00 \mathrm{~g} \\
\text { sample and } \mathrm{V}=4 \mathrm{~mL} \text { hydrolysate with dilution } \\
\text { factor } \mathrm{f} . \mathrm{d}=6.25\end{array}$ & 0.013 & 0.010 & 0.005 & 0.010 & 0.009 & 0.006 & 0.012 \\
\hline Statistical results for Hyp & $n=$ & e of & & & & & \\
\hline Mean value & \multicolumn{7}{|c|}{0.009286} \\
\hline STDEV & \multicolumn{7}{|c|}{0.003068} \\
\hline LOD collagen $=3^{8}$ STDEV & \multicolumn{7}{|c|}{0.01} \\
\hline LOQ collagen $=10^{\circ} \mathrm{STDEV}$ & \multicolumn{7}{|c|}{0.03} \\
\hline $\mathrm{LOD}=3 * \mathrm{LOQ} / 10$ & \multicolumn{7}{|c|}{0.01} \\
\hline
\end{tabular}

\begin{tabular}{|l|c|}
\hline & Mean absorbances obtained for witness samples \\
\hline For sample set I & 0.034 u.a. $<0.040$ u.a.; \\
\hline For sample set II; & 0.038 u.a. $<0.040$ u.a \\
\hline For sample set III. & 0.036 u.a. $<0.040$ u.a \\
\hline LOD $=3^{*}$ SD & $0.05 \mu \mathrm{g} / \mathrm{mL} \quad(0.01 \% \mathrm{~m} / \mathrm{m})$ \\
\hline LOQ $=10^{*}$ SD & $0.2 \mu \mathrm{mL} \quad(0.03 \% \mathrm{~m} / \mathrm{m})$. \\
\hline Recovery $=80-120 \% ;$ & $106.7 \% ;$ \\
\hline RSD $=\max 20 \%$ & $\mathrm{RSD}_{\mathrm{r}}=17.1 \%$ \\
\hline
\end{tabular}

Table 6

ANALYSIS OF COMPLIANCE WITH PERFORMANCE CRITERIA FOR RECOVERY 
Table 7

DATA FOR REPEATABILITY FOR SETS OF DOUBLE SAMPLES AND THE STANDARD HYP. (\%) SET

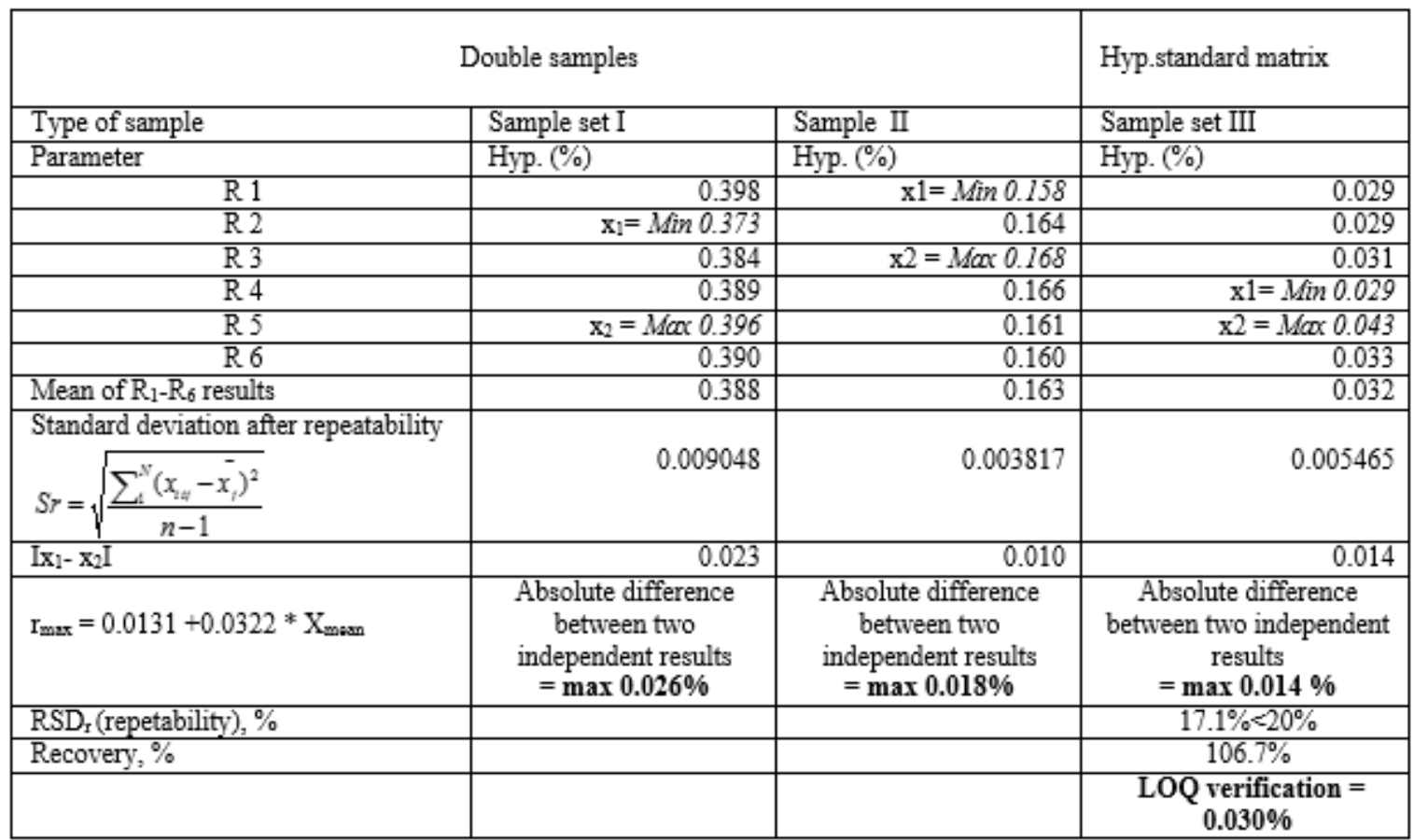

the same method in the same laboratory by the same operator using the same apparatus and $X_{\text {mean }}$ is the average of the two results of the content of the hydroxyproline. Repeatability conditions are verified based on results obtained with the same method, identical samples, in the same laboratory, by the same operator, using the same equipment. The following parameters are used: $r=$ repeatability limit, S-repeatability standard deviation, $x_{\text {: }}$ determined value for each experiment, $X_{\text {men }}$ - mean value of experiments. Three sets of samples, each analyzed in 6 repetitions, were taken into study, in the same laboratory, by different analysts, using the same equipment, in different days, separated by a long interval of time. Results are presented in table 7. The following was noted: for set I $r_{\text {max }}=0.026 \%$, for a mean value of $0.388 \% \mathrm{Hyp}$. and $\left|x_{1}-x_{2}\right|$ $=0.023<r_{\text {max }}$; for set $I I-r_{\text {max }}=0.018 \%$, for a mean value of $0.163 \% \mathrm{Hyp}$. and $\left|\mathrm{x}_{1}-\mathrm{x}_{2}\right|^{\mathrm{max}}=0.010<\mathrm{r}_{\text {max }^{\prime}}$ and for set III (standard solution) $-r_{\text {max }}=0.014 \%$, for a mean value of $0.032 \%$ Hyp. (LOQ) and $\left|\mathrm{x}_{1}-\mathrm{X}_{2}\right|=0.014 \%=r_{\text {max }}$.

Results are within the established performance criteria because the condition for absolute difference is met: $\Delta=$ $\left|\mathrm{X}_{1}-\mathrm{X}_{2}\right| \leq \mathrm{r}_{\text {max }}$. (where $\Delta$ is the absolute difference between the double max $^{\prime}$ samples of the routine determinations is and $r_{\text {max }}$ is the calculated repeatability limit- RSD (repetability) is usually refers to the standard deviation of simultaneous duplicates or replicates, Sr.).

\section{Accuracy (Exactitude), Bias and Precision}

Accuracy is a systematic error expressed as the difference between the average value for a high number of repeated determinations and the real value according to equation (6) [30]. Table 8 presents the results which prove the compliance with performance criteria for accuracy.

Exactness measures closeness between results of measurements and the accepted real value and is determined through recovery experiments from samples with known added concentration standard [30]. Bias characterizes the systematic error of an analytical procedure and is equal to the mean deviation (positive or negative) of analytical results compared to the real value (known or attributed) according to equation (7).

$$
\begin{aligned}
& \text { Accuracy }=X_{\text {mean }}-\text { Reference value } \\
& \text { Bias } \%=100 \frac{X_{\text {mean }}-\text { Reference value }}{\text { Reference value }}
\end{aligned}
$$

Fidelity conveys the closeness between a result of test and the accepted reference value and it is usually expressed as a measure of error [30]. Precision refers to reaching an agreement between independent testing results, obtained on the basis of predetermined stipulated conditions. The measure of precision is typically expressed through imprecision terms and is evaluated as the standard deviation of the test's results. It is the random error. Lower precision is determined by a higher standard deviation. The fidelity of the method has been tested using the certified reference material (TET003RM from FAPAS) [31], for a short period of time, and the accuracy, precision and fidelity were evaluated in the specified conditions. The certified reference value is $0.805 \% \mathrm{Hyp} . \pm 0.028 \%$, and the data obtained is presented in table 9 . Data for the evaluation of method precision presented in table 10 confirm the performance characteristics which comply with the legal and laboratory-imposed requirements.

Table 8

COMPLIANCE WITH PERFORMANCE CRITERIA FOR ACCURACY

\begin{tabular}{|l|l|l|l|l|l|l|l|l|}
\hline Parameter & 1 & 2 & 3 & 4 & 5 & 6 & 7 & 8 \\
\hline$\%$ Hyp. & 0.761 & 0.738 & 0.785 & 0.766 & 0.734 & 0.798 & 0.811 & 0.806 \\
\hline Accuracy \% & \multicolumn{7}{|l|}{$\Delta_{\mathrm{m}}=\mathrm{Ic}_{\mathrm{m}}$-C CIRc I $=0.071<0.08$} \\
\hline Parameter & 9 & 10 & 11 & 12 & 13 & 14 & 15 & Mean value \\
\hline$\%$ Hyp. & 0.810 & 0.828 & 0.826 & 0.822 & 0.855 & 0.848 & 0.834 & $\begin{array}{c}0.801467 \\
(\text { f.d. }=2)\end{array}$ \\
\hline Accuracy \% & & & & & & & & \\
\hline
\end{tabular}




\begin{tabular}{|l|c|}
\hline Sample type & $\begin{array}{l}\text { Certified reference material MRC } \\
\text { - FAPAS TET 003 RM }\end{array}$ \\
\hline Certified value \% Hyp. & 0.805 \\
\hline Mean accuracy = certified value mean, \% Hyp. & 0.004 \\
\hline Bias (exactness error) & 0.5 \\
\hline SR, \% Hyp. & $0.037: 2=0.019$ \\
\hline RSD \% (CVR \%) & 4.6 \\
\hline Fidelity, \% & 99.5 \\
\hline
\end{tabular}

Table 9

DETERMINING ACCURACY, BIAS, AND FIDELITY OF THE METHOD

(8):

-SR = standard deviation for $\mathrm{n}$ participants.

RSD \% relative standard deviation according to equation

$$
R D S=\frac{\mathrm{SD}}{\mathrm{X}_{\operatorname{man}}} 100
$$

$-C V R \%$ is the coefficient of variation for $n$ participants and is declared in percent by Eurachem Guide definition [26].

\begin{tabular}{|c|c|c|c|c|}
\hline \multirow{3}{*}{$\begin{array}{l}\text { Fidelity, MRC - FAPAS TET } 003 \mathrm{RM} \text {, } \\
\text { repeated analysis under reproducibility } \\
\text { conditions } \Delta \mathrm{m}[31]\end{array}$} & \multicolumn{2}{|l|}{$\mathrm{C}_{\text {thessotic }} \%(\mathrm{~m} / \mathrm{m})$ Hyp. } & \multicolumn{2}{|c|}{0.805} \\
\hline & \multicolumn{2}{|l|}{$\mathrm{C}_{\max } \%(\mathrm{~m} / \mathrm{m}) \mathrm{Hyp}$. } & \multicolumn{2}{|c|}{0.801} \\
\hline & \multicolumn{2}{|c|}{$\Delta \mathrm{m}=\mathrm{Ic}_{\text {mosm }}-\mathrm{C}_{\text {theossotic }} \mathrm{I} \%(\mathrm{~m} / \mathrm{m}) \mathrm{Hyp}}$. & \multicolumn{2}{|c|}{0.004} \\
\hline \multirow{4}{*}{$\begin{array}{l}\text { Method precision } \\
\text { - repeatability double sample evaluation } \\
\text { (laboratory sample), Limit r, [23] } \\
\text { - reproducibility through inter-comparison, } \\
\text { Limit } R,[23]\end{array}$} & C Hyp. \% & $0.03(\mathrm{LOQ})$ & 0.2 & 0.4 \\
\hline & $\begin{array}{l}\mathrm{Ix}_{1}-\mathrm{X}_{2} \mathrm{I} \\
\text { Limit } \mathrm{r}=0.0131+0.0322 * \mathrm{X}_{\max }\end{array}$ & $\begin{array}{l}0.014 \\
0.014\end{array}$ & $\begin{array}{l}0.010 \\
0.018\end{array}$ & $\begin{array}{l}0.023 \\
0.026\end{array}$ \\
\hline & $\begin{array}{l}\mathrm{Ix}_{1}-\mathrm{x}_{2} \mathrm{I} \\
\text { Limit } \mathrm{R}=0.0195+0.0529 * \mathrm{X}_{\max }\end{array}$ & - & - & $\begin{array}{l}0.040 \\
0.042\end{array}$ \\
\hline & $\mathrm{RSD}_{\mathrm{K}}$ ( repetability) $\%$ & 3.68 & 2.21 & - \\
\hline $\begin{array}{l}\text { Extended uncertainty }(\mathrm{k}=2, \text { for level of } \\
\text { confidence } 95 \%) \text { for } 0.4 \% \mathrm{~m} / \mathrm{m}) \text { Hyp. } \\
\mathrm{U}_{c}(\%)\end{array}$ & \multicolumn{4}{|l|}{$\begin{array}{l} \pm 0.038 \%(\mathrm{~m} / \mathrm{m}) \text { Hyp. } \\
\mathrm{U}_{\mathrm{c}}(\%)=9.7 \%\end{array}$} \\
\hline
\end{tabular}

$-\Delta \mathrm{m}$ is the absolute difference between the measurement average and the theoretic certified value, $C_{\text {mean }}$ is the measurement average value and $c_{\text {theoretic }}$ is the theoretic certified value, $-X_{\text {mean }}$ is the mean value of measurement.

\section{Uncertainty}

The calculation of combined and extended uncertainty for Äm (the absolute difference between the measurement average and the reference certified value) and $U_{\Delta}$ (the increased uncertainty of the difference between the result and the certified value corresponding to a confidence interval of $95 \%$ ) when using a MRC (certified reference material) $[27,28,31]$, is based on $\mathrm{S}_{\text {pias }}=$ standard deviation for $n$ determinations, $n=$ number of determinations, and $\mathrm{u}_{\text {cref }}=$ uncertainty of the reference certified value conveyed by equation (9). The absolute differene between mean of measurements $C_{m}$ and certified value $C_{\text {MRC }}$ is $\Delta_{m}$, as conveyed by equation (10):

$$
\begin{gathered}
u_{\text {Slas }-2 \mathrm{NC}}=\sqrt{(\text { Bias })^{2}+\left(\frac{S_{\text {Slas }}}{\sqrt{n}}\right)^{2}+\left(u_{\text {Cosf }}\right)^{2}} \\
\Delta_{\mathrm{m}}=\mathrm{Ic}_{\mathrm{m}}-\mathrm{c}_{\mathrm{MRC}} \mathrm{I}
\end{gathered}
$$

Combined uncertainty associated with the mean measured value, $u_{m}$, and with the certified value, is given by equation '(11). The extended uncertainty of the difference between the result and the certified value corresponding to a confidence interval of approximately $95 \%$, is obtained by multiplying $u_{\ddot{A}}$ with a cover factor $k$, which is usually 2 and is conveyed by equation (12), [27, 28].

$$
\begin{aligned}
& U_{\Delta}=\sqrt{u_{m}{ }^{2}+u_{M A C}{ }^{2}} \\
& \mathrm{U}_{\Delta}=2 \mathrm{xu}_{\Delta}
\end{aligned}
$$

RDS (relative standard deviation or variation coefficient CVR) is calculated using equation (8) $[27,28] . U_{\ddot{A}}$ is the extended uncertainty. $u_{\ddot{A}}$ is the uncertainty associated to the mean measured value and the certified value. Because the obtained value is outside the linearity domain, $1+1$ sample dilution was performed (dilution factor f.d. $=2$ ) so as to fit on the calibration curve. In case of a certified reference material, averaged content deviation, determined experimentally, and the certified value must be situated within a limit of $\pm 10 \%$. Fidelity (in percentages) must be within the $90-110 \%$ interval. Recovery data are acceptable if they are within a limit of $\pm 10 \%$ from the target value. From the data presented in table 11, for evaluation of method performance, $\Delta_{\mathrm{m}}$ is compared to $U$ and it can be observed that there is no significant difference between measurement result and certified value because $\Delta m \leq U_{\text {, [31]. Table } 12 \text { presents }}$ the centralized values of the budget of uncertainties for measurement.

Determination of uncertainty sources was accomplished through the Ishkawa diagram presented in figure 2.

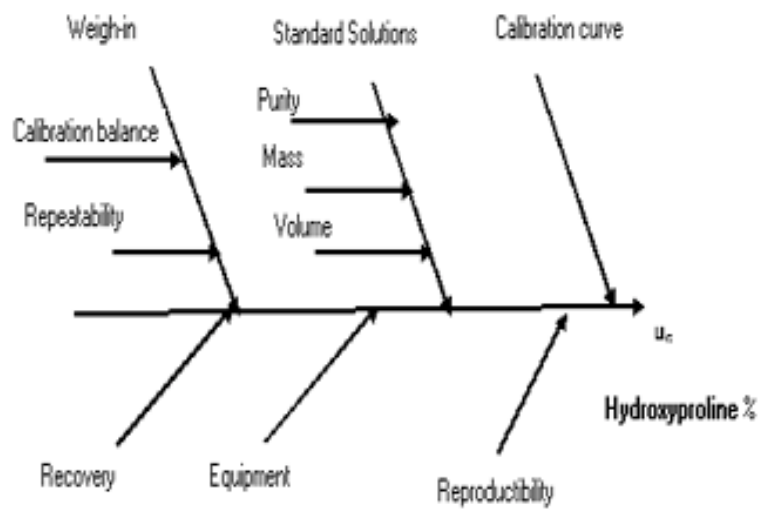

Fig.2 Ishikawa diagram for the determination of the sources of uncertainty 
Table 11

RESULTS OBTAINED FOR EVALUATING UNCERTAINTY

\begin{tabular}{|c|c|}
\hline Date regarding uncertainty & Obtained values \\
\hline$\Delta \mathrm{m}=\mathrm{I} \mathrm{c}$ - $\mathrm{C}_{\mathrm{MRC}} \mathrm{I}$ & $\Delta \mathrm{m}=\mathrm{I} 0.805-0.801 \mathrm{I}=0.004 \%$ Hyp. \\
\hline $\begin{array}{l}\text { Uncertainty associated with measurement result } \mathrm{u}_{m}= \\
\mathrm{S}_{\mathbb{R}}\end{array}$ & $\mathrm{u}_{m}=0.037 \%$ Hyp \\
\hline Uncertainty associated with certified value uMre & $\begin{array}{l}\text { UMaRC }=0.028: 2=0.014 \% \text { Hyp (MRC solution standardization } \\
\text { certificate) }\end{array}$ \\
\hline $\begin{array}{l}\text { Combined uncertainty associated to the mean } \\
\text { measured value and the certified value } \\
u_{s}-{\sqrt{u_{n}^{2}+u_{u a c}}}^{2}\end{array}$ & $u_{\Delta}=\sqrt{0.037_{m}^{2}+0.014^{2}}=0.04 \%$ Hyp \\
\hline Extended uncertainty $\mathrm{U}_{\Delta}=2 \mathrm{x}$ u & $\begin{array}{l}\mathrm{U}_{\Delta}=2 \times 0.04=0.08 \% \text { Hyp. } \\
\text { Differences were obtained } \Delta \mathrm{m}<\mathrm{U}_{\Delta}\end{array}$ \\
\hline Fidelity (as percentage) & $99.5 \%$, within the $90 \%-110 \%$ interval \\
\hline
\end{tabular}

Table 12

CENTRALIZED VALUES OF THE BUDGET OF UNCERTAINTIES FOR MEASUREMENT

\begin{tabular}{|c|c|c|c|}
\hline Parameter & $\mathrm{X}$ values & $\begin{array}{l}\text { Uncertainty } \\
\mathrm{u}(\mathrm{x})\end{array}$ & $\begin{array}{l}\text { Relative standard } \\
\text { uncertainty } \mathrm{u}(\mathrm{x}) / \mathrm{x}\end{array}$ \\
\hline Sample mass, g & 4 & 0.0016 & $0.0016: 4=0.0004$ \\
\hline Standard calibration solution & $5 \mu \mathrm{g} / \mathrm{mL}$ Hyp. & $0.06 \mathrm{mg} / \mathrm{L}$ & $0.06: 5=0.012$ \\
\hline $\begin{array}{l}\text { Spectrophotometer, for } \lambda=558 \mathrm{~nm} \\
\text { and an absorbance }=0.300 \text { u.a. } \\
\text { corresponding to } \\
\mathrm{c}=1.833 \mu \mathrm{g} / \mathrm{mL} \text { Hyp. }\end{array}$ & $\begin{array}{l}0.02: 2=0.01 \text { u.a., } \\
\text { corresponding to } \\
\mathrm{c}=0.02 \mu \mathrm{g} / \mathrm{mL} \text { Hyp. read on the } \\
\text { calibration curve }\end{array}$ & $0.02 \mu \mathrm{g} / \mathrm{mL}$ & $0.02: 1.833=0.010\left(\mathrm{u}_{\text {schip }}\right)$ \\
\hline $\begin{array}{l}\text { Drawing of the calibration curve } \\
\text { (standard deviation } \mathrm{Sx}_{0} \text { ) }\end{array}$ & $\mathrm{X}_{\bmod }=1.833 \mu \mathrm{g} / \mathrm{mL}$ & 0.012 & $0.012: 1.833=0.006$ \\
\hline
\end{tabular}

\begin{tabular}{|c|c|}
\hline Combined uncertainty/method $\mathrm{u}_{\mathrm{v}}$ & 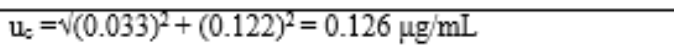 \\
\hline Extended uncertainty $\mathrm{U}_{\mathrm{c}}$ & $\begin{aligned} \mathrm{Uc} & =20 \times 126=0.252 \mu \mathrm{g} / \mathrm{mL} \\
& =0.039 \% \text { Hyp, pt. K=2. }\end{aligned}$ \\
\hline Percentage uncertainty, U\% & $\mathrm{U} \%=0.252 \mu \mathrm{g} / \mathrm{mL} \times 100 / 2.56 \mu \mathrm{g} / \mathrm{mL}=9.84 \%$ \\
\hline $\mathrm{R}_{\max }=0.0195+0.0529 * \mathrm{X}_{\max }[23]$ & $\begin{aligned} \mathrm{R}_{\max } & =0.062 \% \text { Hyp } \\
& =7.74 \% \text { from the mean obtained by } 0.801 \% \text { Hyp. }\end{aligned}$ \\
\hline
\end{tabular}

Table 13

QUANTIFICATION OF UNCERTAINTY COMPONENTS OF THE METHOD AT $0.400 \%$ HYP

Table 14

DETERMINING VALUE INTERVALS FOR HYDROXYPROLINE CONTENT (İG/ML), NEEDED TO DRAW A SHEWHART CHART ACCORDING TO SR ISO 3496:1997 [23]

\begin{tabular}{|c|c|c|c|c|c|c|}
\hline Sample no. & 1 & 2 & 3 & 4 & 5 & 6 \\
\hline Hydroxyproline $\mu \mathrm{g} / \mathrm{mL}$ & 4.167 & 4.566 & 4.539 & 4.087 & 3.906 & 4.067 \\
\hline Sample no. & 7 & 8 & 9 & 10 & 11 & 12 \\
\hline Hydroxyproline $\mu \mathrm{g} / \mathrm{mL}$ & 3.982 & 3.615 & 4.063 & 4.350 & 4.262 & 4.393 \\
\hline Mean value & $\mathrm{S}_{\mathrm{R}}$ & $2 \mathrm{SD}$ & $3 \mathrm{~S}_{\mathrm{R}}$ & \multicolumn{2}{|c|}{ Mean value $=2 \mathrm{SD}$} & Mean value \pm 3 SD \\
\hline $\begin{array}{l}4.166 \mu \mathrm{g} / \mathrm{mL} \\
\text { Target value }=0.651 \%\end{array}$ & 0.274 & 0.548 & 0.822 & \multicolumn{2}{|c|}{$3.618-4.714$} & $3.344-4.988$ \\
\hline
\end{tabular}

Quantification of uncertainty components of the method at $0.400 \%$ Hyp. is presented in table 13 . It can be noticed that the calculated percentage uncertainty $>$ maximum limit of uncertainty, $\quad U \%>R_{\max } \%$

The map of control for Hyp.

$$
\begin{aligned}
& \text { Valve of Hyp, } \mu \mathrm{g} / \mathrm{mL} \\
& \text { Upper limit of operation } \\
& 5.000 \\
& \text { The warning limit } \\
& 4.500 \\
& 4.000 \\
& \text { The lower limit of warning } \\
& 3.500 \\
& \text { The lower limit of operation } \\
& 3.000
\end{aligned}
$$

Stability and control chart (internal reproducibility)

Stability refers to stability over time of the analyzed substance from the matrix. The control chart is a visual surveillance instrument of the analytical measurement

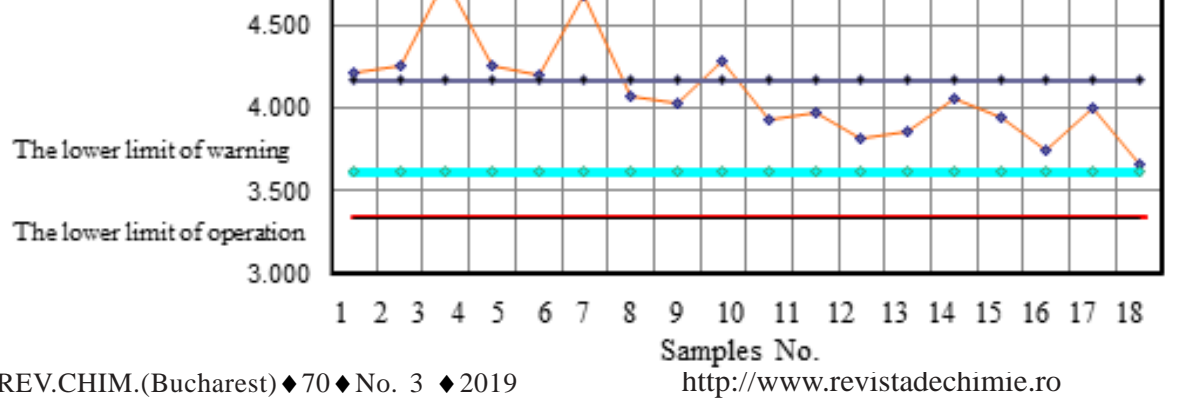

Fig.3 Graphical representation of the results on the control map 


\begin{tabular}{|c|c|c|c|c|}
\hline Type of extract & $\begin{array}{c}\text { Hydroxyproline } \\
\text { content } w \%\end{array}$ & $\begin{array}{c}\text { Collagen } \\
\text { content } w \%\end{array}$ & LOD & LOQ \\
\hline in $0.5 \mathrm{M}$ acetic acid & 0.119 & 0.95 & 0.01 & 0.03 \\
\hline in $0.1 \mathrm{M} \mathrm{HCl}$ & 0.085 & 0.68 & 0.01 & 0.03 \\
\hline
\end{tabular}

Table 15

HYDROXYPROLINE AND COLLAGEN CONCENTRATION IN COLLAGEN HYDROLYSATE EXTRACTED FROM GREY MULLET FISH

process, denoted by W. Shewhat, chart may be considered as a principal instrument for internal control. A sample of concentrated protein product extracted from saltwater fish was analyzed and the collagen hydrolysate was tested so as to appreciate hydroxyproline stability at $4^{\circ} \mathrm{C}$. This is useful for verifying the method and designing a control map (fig.3). The followings were established: central line (mean of registered valued), intervention limits (mean $\pm 3 S D$ ) and warning limits (mean $\pm 2 S D$ ); their vaues are presented in table 14 and figure 3 .

\section{Results obtained on collagen hydrolysate extracted from Black Sea Grey Mullet fish}

The method for determining hydroxyproline contentfrom collagen isolated from Grey Mullet fish skin was deemed valid. Results are presented in table 15. Collagen hydrolysate was extracted from Black Sea Grey Mullet fish through three different extraction procedures: acid treatments (ASC) with $0.5 \mathrm{M}$ acetic acid and $0.1 \mathrm{M}$ chlorhydric acid and pepsin, respectively (PSC).

Extraction output was calculated as percentage from the dry mass of the extracted collagen (Mo) compared to the wet mass of the initial fish skin (M) using equation (13):

$$
\text { Output } \%=\mathrm{Mo} / \mathrm{M} * 100
$$

The values of collagen extraction outputfrom Grey Mullet fish skin according to the applied treatment are presented in table 16.

Table 16

COLLAGEN EXTRACTION OUTPUT FROM GREY MULLET FISH SKIN ACCORDING TO THE APPLIED TREATMENT

\begin{tabular}{|l|c|}
\hline Treatment & Extraction output, W \% \\
\hline ASC $0.5 \mathrm{M}$ acetic acid & 47.3 \\
\hline ASC $\mathrm{HCl} 0.1 \mathrm{M}$ & 31.5 \\
\hline PSC & 7.1 \\
\hline
\end{tabular}

\section{Conclusions}

The spectrophotometric method for determination of hydroxyproline content in saltwater fish protein products has been validated according to performance criteria. The obtained standard curve is linear, the variation coefficient of the method is $V x_{0}=3.162<10 \%$, correlation coefficient $\mathrm{R}=0.9985>0.995$, and informant value compared to $\mathrm{F}=$ 10.97 , is $P G=1.7399<10.97$. Through the homogeneity test, it was established that dispersions are homogenous. Because linearity was respected on the entirety of the chosen work domain, the calibration curve meets performance criteria.

The performance criteria have followed: limit of detection and of quantification, accuracy/fidelity, stability/ sturdiness, repeatability, and measurement uncertainty. All are within the requirements, which show that the method is adequate for the analysis of hydroxyproline content from hydrolysate obtained from fish. The validated method was applied for the quantitative determination of collagen content in Grey Mullet fish and to establish collagen extraction output.

\section{References}

1.SHOULDERS, M.D., RAINES, R.T., Annual Review of Biochemistry, 78, 2009, 929-958.

2.BHATTACHARJ EE, A., BANSAL, M., LIFE, 57, 3, 2005, 161-172.
3.IGNAT'EVA, N. YU., DANILOV, N.A., AVERKIEV, S.V., OBREZKOVA, M.V., LUNIN, V.V., SOBOL, E.N., J. Anal. Chem., 62, 1, 2007, 51-57. 4.LAFARGA T., HAYES M., Meat Science 98 (2), 2014, 227-239.

5.KIM H.K., KIM Y.H., PARK, H.J. AND LEE N.H. Fisheries Science 79 (5), 2013, 849-856.

6.GOMEZ-GUILLEN, M.C., GIMENEZ B., LOPEZ-CABALLERO M.E., MONTERO M.P., Food Hydrocolloids, 25, 2011, 1813-1827.

7.GAIDAU C., PETICA A., MICUTZ M., DANCIU M., VLADKOVA T., Cent. Eur. J. Chem. 11 (6), 2013, 901-911.

8.ADDAD S, J EAN-YVES E, FAYE C, SYLVIE RICARD-BLUM S, LETHIA C., Mar Drugs. 9 (6), 2011, 967-983.

9.PERUMAL P. KRISHNAN S, International Journal of Pharmacy and Pharmaceutical Sciences, 5 (3), 2013, 698-701.

10.SULEA D., MICUTZ M., ALBU M.G., STAICU T., LECA M., POPA L., GHICA M.V., Rev. Roum. Chim. 56 (8), 2011, 811-817.

11.SILVIPRIYA KS, KRISHNA KUMAR K, BHAT AR, DINESH KUMAR B, ANISH JOHN, J. Appl. Pharm. Sci., 5 (03), 2015, 123- 127.

12.HOYER B, BERNHARDT A, LODE A, HEINEMANN S, SEWING J, KLINGER M, NOTBOHM H, GELINSKY M., Acta Biomater, 10 (2), 2014, 883-892.

13.J IN-FENG D, XIU-RONG SU, CHUN-DAN Z., J. Food Science, 31 (24), 2010, 19-23.

14.SHANMUGAM V, RAMASAMY P, SUBHAPRADHA N, and all, African J ournal of Biotechnology, 11 (78), 2012, 14326-14337.

15.KA-JEONG L, PARK H.Y, KIM Y.K, PARK J.I, YOON H.D. , J. Korean Soc. Appl. Biol. Chem. 52 (3), 2009, 221-226.

16.DESHMUKH K, NIMNI M.E, J.Biochemistry, 10 (9), 1971, 1640-1647. 17.CHERIM M., STANCIU G.A, RASIT E. Y., CADAR E., J ournal of Science and Arts, 4(41), 2017, 795-802.

18.MACKENZIE S.L., TENASCHUK D., J Chromatog, 104, 1975, 176-177. 19.PEFIER C., RONZIERE M.C., RATTNER A., FREY J ., J. Chromatog., $182,1980,155-162$.

20.QI, X., BALDWIN, R. P., Electroanal, 6, 5-6, 1994, 353-360.

21.AFKHAMI A., MADRAKIAN T., MALEKI A., Anal. Science, Feb. 22, 2006, 329-331.

22.CARLSON, C.G., Determination of Hydroxyproline Content as a Measure of Fibrosis in Nondystrophic and Dystrophic Skeletal Muscle, Wellstone Muscular Dystrophy Center Washinton, DC, 2014, 1-10. 23.*** ISO 3496:1997 Meat and meat products - Determination of hydroxyproline content.

24.MACOVESCU G., CHELARU C, ALBU KAYA M.G., Leather and Footwear J ournal 16, 2, 2016, 147-162.

25.EDWARDS CA, O'BRIEN WD JR., Clin. Chim. Acta. 4 (2), 1980, $161-$ 171.

26.*** EURACHEM guide, The Fitness for Purpose of Analytical Methods. A Laboratory Guide to Method Validation and Related Topics, Second Edition, 2014.

27.*** EURACHEM/CITAC Guide CG 4, Quantifying Uncertainty in Analytical Measurement, Second Edition, 2000.

28.*** EURACHEM/CITAC Guide, Measurement Uncertainty Arising from Sampling. A Guide to Methods and Approaches, 2007.

29.*** ISO 8466-1: Water quality. Part 1: Statistical evaluation of the linear calibration function, 1990.

30.*** ISO 5725-1Accuracy (trueness and precision) of measurement methods and results -Part 1: General principles and definitions, 1994.

31.THOMAS LINSINGER, ERM (European Reference Materials) Comparison of the result of a measurement with the certified value, 2010

Manuscript received: 3.05 .2018 